\title{
KESEIMBANGAN TUBUH DAN KOORDINASI MATA KAKI DENGAN KEMAMPUAN PASSING SEPAK SILA DALAM PERMAINAN SEPAK TAKRAW
}

\author{
Abdul Gaffar ${ }^{1}$, Maulidin ${ }^{2}$ dan Intan Kusuma Wardani ${ }^{3}$ \\ ${ }^{1}$ Program Studi Pend. Olahgara dan Kesehatan, Fakultas Pendidikan Olahraga dan Kesehatan Undikma \\ Email: abdulgafar21@gmail.com
}

\begin{abstract}
Abstrak:
Permainan sepak takraw merupakan permainan yang dilakukan lapangan empat persegi panjang, baik terbuka maupun tertutup, serta bebas dari semua rintangan terkecuali net sebagia penghalang. Berdasarkan hasil observasi klub putra pulau maringkik masih kurang sempurna kemampuan passing dengan menggunakan sepak mula atau sepak sila dalam permainan sepak takraw tersebut.Tujuan penelitian ingin mengetahu ada atau tidak adanya hubungan keseimbangan dan koordinasi mata-kaki dengan passing menggunakan sepak mula dalam permainan sepak takraw. Sampel yang digunakan dalam penelitian ini 14 orang yang tergabung dalam klub sepak takraw pulau maringgkik. Analis data an menggunakan korelasi berganda. Hasil analisis data untuk hipotesis I diperoleh t-hitung sebesar 0,636 ttabel dengan $\mathrm{db}=14$ dan taraf signifikan 5\% ternyata di peroleh t-tabel sebesar 0,532. Ini berarti t-hitung lebih besar dari t-tabel atau $(0,636>0,532)$ berarti ada hubungan. Sedangkan hipotesis II diperoleh thitung sebesar 0,6267 dan t-tabel sebesar 0,532 ini berarti t-hitung lebih besar dari t-tabel atau $(0,626>$ 0,532) berarti ada hubungan dan hiporesis ke III diperoleh t-hitung sebesar 1,307 dan t-tabel sebesar 0,532 ini berarti t-hitung lebih besar dari t-tabel atau $(0,626>0,532)$ Jadi hasil kesimpulan dari penelitian ini signifikan, sehingga penelitian ini adalah: "'Ada hubungan keseimbangan tubuh dan koordinasi matakaki dengan kemampuan passing sepak sila dalam permainan sepak takraw klub putra pulau Maringkik.

Kata Kunci: keseimbangan tubuh, koordinasi mata kaki dan hasil passing
\end{abstract}

\section{PENDAHULUAN}

Permainan sepak takraw merupakan permainan yang dilakukan lapangan empat persegi panjang, rata, baik terbuka maupun tertutup, serta bebas dari semua rintangan. Lapangan dibatasi oleh net. Bola yang dipakai terbuat dari rotan atau plastik (synthetic fibre) yang dianyam bulat. Permainan ini menggunakan seluruh anggota tubuh, kecuali tangan dan lengan. Bola dimainkan dengan mengembalikannya ke lapangan lawan melewati net. Permainan ini dilakukan oleh dua regu, masing-masing terdiri dari 3 orang pemain dan 1 pemain cadangan. Tujuan dari setiap pemain adalah mengembalikan bola ke lapangan lawan (Pandjaitan, 2002: 29).

Teknik merupakan kemampuan dasar yang dimiliki individu untuk menentukan keberhasilannya. Keterampilan teknik dasar itu diperlukan dalam enghadapi pertandingan yang sebenarnya, sehingga para pemain dapat menampilkan suatu bentuk permainan yang menarik dan bagus dengan tingkat keterampilan yang tinggi. Agar menjadi seorang pemain sepak takraw yang baik, maka teknik dasar dalam permainan sepak takraw harus betul-betul dikuasai (Sumosardjuno, 2008: 32).

Dalam penelitian ini akan diteliti tentang passing. Passing dimana seorang membagikan bola atau mengoper bola dengan menggunakan kaki (Tony, 2006: 25). Untuk mendapatkan seorang atlet sepak takraw yang berprestasi, harus memiliki 4 aspek yaitu aspek fisik, teknik, taktik dan mental. Dari ke empat aspek tersebut, aspek fisik memegang peranan yang sangat penting terhadap aspek-aspek lainnya, karena hal itu berhubungan erat dengan kesiapan kondisi fisik seorang atlet untuk menunjang penguasaan aspek-aspek yang lain, oleh sebab itu dalam setiap program latihan, aspek ini selalu menjadi aspek prioritas utama khusus di dalam menjaga daya tahan seorang atlet. Adapun komponen-komponen dari aspek fisik ini adalah daya tahan, daya ledak, 
kecepatan, kekuatan, kelincahan, keseimbangan, kelenturan, stamina, ketepatan dan koordinasi.

Untuk dapat bermain sepak takraw dengan mahir dan profesional harus apat menguasai teknik-teknik dasar dalam permainan sepak takraw. Teknik dasar dalam permainan sepak takraw merupakan unsur penting dalam permainan sepak takraw. Tanpa penguasaan teknik dasar dengan baik, permainan tidak dapat dimainkan dengan sempurna. Salah satu teknik dasar dalam permainan sepak takraw adalah sepak silaatau sepak mula dan sepak kuda.

Sepak mula adalah menyepak bola dengan menggunakan kaki bagian dalam. Sepak mula digunakan untuk menerima dan menimang/menguasai bola, mengumpan bola dan untuk mengantisipasi serangan lawan. Sedangkan sepak kuda adalah sepakan dengan menggunakan kura kaki atau dengan punggung kaki. Digunakan untuk menyelamatkan bola dari smash lawan, memainkan bola dengan usaha menyelamatkan bola dan mengambil bola yang rendah. Sebagai teknik dasar, maka sepak sila dan sepak kuda harus dikuasai dan dilatih dengan sungguh-sungguh. Sepak mula sangat penting dan harus dikuasai oleh seorang pemain sepak takraw, karena sepak mula merupakan gerak yang dominan dalam permainan sepak takraw. Dapat dikatakan bahwa menyepak itu merupakan ibu dari permainan sepak takraw karena bola dimainkan terbanyak dengan kaki, mulai dari permulaan permainan sampai membuat poin atau angka. (Pandjaitan, 2002: 32).

\section{KAJIAN TEORI}

Sepaktakraw merupakan olahraga kombinasi permainan sepak bola dan bola voli. Mengenai pengertian permainan sepak takraw, menurut Prestasi yang dikutip oleh Pemana (2008: 21), menyatakan bahwa sepak takraw adalah permainan yang dilakukan di atas lapangan empat persegi panjang, rata, baik terbuka dan tertutup, serta bebas dari semua rintangan dan lapangan dibatasi oleh net.

Menurut Darwis, Ratinus (1992: 174), permainan sepak takraw dapat dinyatakan merupakan penggabungan olahraga sepak bola dan bola voli yang membangun ketangkasan dan kebugaran bagi pemainnya. Salah satu aturan mainnya adalah bagi pemain dilarang menyentuh bola dengan tangannya. Permainan adalah suatu kegiatan yang sering dilakukan anak-anak maupun orang dewasa untuk melatih kemampuan yang ada di dalam dirinya (Irianto, 2004: 34). Permainan adalah bagian mutlak dari kehidupan anak dan permainan merupakan bagian integral dari proses pembentukan kepribadian anak (Kosasih, 2005: 39).

Menurut Kosasih (2005: 43), hakikat permainan meliputi membantu pertumbuhan anak, merupakan kegiatan yang dilakukan secara sukarela, memberikan kebebasan untuk anak bertindak, memberikan dunia khayal yang disukai anak, mempuyai unsur berpetualang didalamnya, meletakkan dasar pengembangan bahasa, mempunyai pengaruh yang unik dalam pembentukan hubungan antar pribadi, memberikan kesempatan untuk menguasai diri secara fisik, memperluas minat dan pemusatan perhatian, merupakan cara untuk menyelidiki sesuatu, merupakan cara aneka mempelajari peran orang dewasa, merupakan cara dinamis untuk belajar, menjernihkan pemikiran anak, dapat distruktur secara akademis, merupakan kekuatan hidup dan merupakan sesuatu yang esensial bagi kelestarian hidup.

Menurut Ratinus Darwis (1992: 61), sepak mula adalah sepakan yang dilakukan oleh tekong kearah lapangan lawan sebagai awalan dalam memulai permainan sepak takraw. Sepak mula merupakan hal yang sangat penting, karena dengan sepak mula 
suatu team atau regu dapat mendapatkan poin atau angka. Begitu pula sebaliknya, jika gagal dalam melakukan sepak mula berarti kita telah memberi peluangtim atau regu lawan untuk memperoleh angka.

Sepak mula atau servis itu merupakan suatu kesempatan baik dalam permainan sepak takraw untuk memperoleh angka. Terkadang pemain ingin mendapatkan poin dengan melakukan sepak mula saja. Sehingga sepak mula yang dilakukan begitu keras dan kencang, sehingga bola sering keluar lapangan. Hal ini akan sangat merugikan team atau regu. Adapun tujuan dari sepak mula ini menurut Ratinus Darwis (1992:61), adalah untuk merusak pertahanan lawan sehingga kita dapat menyusun strategi untuk mengacaukan pihak lawan. Oleh sebab itu sepak mula harus dibuat dengan berbagai cara untuk mengacaukan atau membuat tipuan tentang sasaran sepak mula yang akan dilakukan. Tekong seharusnya melakukan sepak mula dengan baik yaitu tempat-tempat yang dianggap lemah dan sulit untuk diraih pihak lawan.

Keseimbangan adalah suatu keadaan seimbang antara tenaga yang berlawanan ( Maemun dan Yudha M. Saputra, 2000: 32). Ismaryati (2006: 48), membagi keseimbangan kedalam dua jenis yaitu, 1) keseimbangan dinamis, 2) keseimbangan statis. Keseimbangan statis adalah kemampuan mempertahankan keseimbangan dalam keadaan diam. Keseimbangan dinamis adalah kemampuan mempertahankan keseimbangan dalam keadaan bergerak. Setiap orang perlu memiliki keseimbangan dalam melakukan aktivitas sehari-hari, misalnya berjalan, berlari, berkendara dan lain sebagainya.

Koordinasi adalah kemampuan otot dalam mengontrol gerak dengan tepat agar dapat mencapai suatu fungsi khusus (Noer, 2006). Menurut Schmidt (1988) dalam Sukadiyanto, koordinasi adalah perpaduan gerak dari dua atau lebih persendian, yang satu sama lainnya saling berkaitan dalam menghasilkan satu keterampilan gerak. Koordinasi merupakan hasil perpaduan kinerja dari kualitas otot, tulang, dan persendian dalam menghasilkan satu gerak yang efektif dan efesien.

Koordinasi adalah kemampuan seseorang dalam mengintraksikan gerakangerakan yang berbeda ke dalam suatu pola gerakan tunggal secara efektif. Koordinasi ini sangat sulit dipisahkan secara nyata dengan kelincahan, sehingga kadang-kadang suatu tes koordinasi juga bertujuan mengukur kelincahan. (Sajoto, 1988). Latihan koordinasi merupakan suatu bentuk latihan gabungan dari tangan dan mata yang dilakukan secara cepat dan bersamaan. Latihan koordinasi sangat tepat diberikan pada permainan tenis meja karena peredaran bolanya sangat cepat dan antisipasi lengan untuk menahan berbagai teknik pukulan selalu siap.

\section{METODE PENELITIAN}

Jenis penelitian ini adalah deskriptif dengan studi korelasional dengan metode korelasi berganda yang bertujuan untuk mengetahui hubugan langsung antar variable, sampel yang digunakan terdiri dari 14 orang yang aktif bermain sepaktakraw, intrumen yang digunakan untuk mengumpulkan data; 1) mengukur keseimbangan menggunakan tes stork stand, untuk anak usia 10 tahun keatas. (Widiastuti, 2015: 50). Waktu yang dicatat adalah waktu yang digunakan untuk mempertahankan keseimbangan dimulai dari aba-aba "YA" sampai tes kehilangan keseimbangan. 2) tes koordinasi mata-kaki. 3) 
Jurnal Cahaya Mandalika, Vol. 2, No. 3, November 2021 ,e- ISSN: 2721-4796

Available online at: http://ojs.cahayamandalika.com/index.php/JCM

Copyright @ 2021 Publisher: Institut Penelitian \& Pengembangan Mandalika Indonesia

Instrumen Penelitian Passing (Nurhasan, 2001). Analis data menggunakan korelasi berganda.

\section{HASIL DAN PEMBAHASAN}

Dengan melihat nilai $\mathrm{N}=15$, taraf signifikan 5\% dari $\mathrm{r}$ tabel menunjukan angka $=$ 0,532. Sedangkan dari hasil perhitungan nilai $\mathrm{r}$ yang diperoleh di atas menunjukkan angka $r$ hitung $=1,307$, jadi bila kita bandingkan antara $r$ hitung dengan $r$ tabel dengan taraf signifikan 5\% maka $r$ hitung lebih besar dari $r$ tabel $(1,307)>(0,523)$.

Keseimbangan adalah keadaan dimana tubuh kita dapat mempertahankan posisinya walaupun telah melakukan gerakan. Keseimbangan sangat diperlukan dalam melakukan sepaksila, ketika menyepak bola takraw, salah satu kaki digunakan untuk menyepak dan kaki yang lain dugunakan untuk bertumpu. Kaki yang dugunakan untuk bertumpu harus mampu mempertahankan kondisi tubuh agar tetap dalam keadaan seimbang, sehingga pelaksanaan sepaksila dapat berjalan sesuai yang dikehendaki. Selain itu jika tubuh dalam keadaan seimbang pada saat menyepak bola takraw, pemain dengan mudah menentukan arah sepakan bola dengan tenang dan sesuai arah yang diinginkan. Terlebih pada saat mengumpan kepada teman yang akan melakukan smash. Oleh sebab itu keseimbangan perlu ditingkatkan untuk mengembangkna kemampuan sepaksila menjadi lebih baik. Dengan demikian unsur keseimbangan dapat memprediksi terhadap kemampuan sepaksila pada permainan sepaktakraw. Hal ini mengandung makna bahwa, apabila nilai keseimbangan tergolong baik, maka akan diikuti dengan nilai kemampuan sepaksila pada permainan sepaktakraw yang baik pula. Begitu pula sebaliknya, apabila nilai keseimbangan yang kurang baik, maka akan diikuti dengan nilai kemampuan sepaksila pada permainan sepaktakraw yang kurang baik pula.

Secara fisiologis koordinasi sebagai kerja sama dari sistem syaraf pusat dengan otot untuk menghasilkan tenaga, baik inter maupun intramusculer. Dengan pengertian luas, koordinasi sering juga merujuk pada istilah atau nama untuk beberapa kemampuan yang mendukung kerja sama dari proses gerak yang berbeda, misalnya dalam belajar, koordinasi dibedakan atas koordinasi kasar (kemampuan belajar gerak), koordinasi halus (kemampuan mengendalikan gerak), dan koordinasi halus stabil (kemampuan merubah dan menyesuaikan gerak). Dengan adanya koordinasi mata-kaki pemain mampu menampilkan suatu model keterampilan gerak dalam melakukan sepaksila, dapat menggabungkan gerakan menjadi satu bagian yang kompleks yang memadukan tungkai atau kaki dengan penglihatan menjadi terpadu dalam suatu pola gerakan yang disertai perasaan kontrol bola yang cermat pada bagian-bagian kaki. Hal ini mengandung makna bahwa, apabila nilai koordinasi mata-kaki tergolong baik, maka akan diikuti dengan nilai kemampuan sepaksila dalam permainan sepaktakraw yang baik pula. Begitu pula sebaliknya, apabila nilai koordinasi matakaki yang kurang baik, maka akan diikuti dengan nilai kemampuan sepaksila permainan sepaktakraw yang kurang baik pula

\section{SIMPULAN}

Berdasarkan analisa data yang sudah dilakukan, dapat diketahui bahwa $\mathrm{r}$ hitung $>\mathrm{r}$ tabel $(1,307>0,532)$ maka terdapat hubungan secara langsung keseimbangan tubuh $\left(x_{1}\right)$ dan koordinasi mata tangan $\left(x_{2}\right)$ dengan passing menggunakan sepak mula dalam permainan sepak takraw.

\section{DAFTAR PUSTAKA}


Arikunto, Suharsimi, 1996., Prosedur Penelitian Suatu Pendekatan Praktek. Renika Cipta, Jakarta. Ateng, Abdul, Kadir. 1992. Azas dan Landasan Pendidikan Jasmani. Dirjen Dikti, Jakarta.

Harsono. 1998. Coaching dan Aspek -Aspek Psychologi Dalam Coaching. Depdikbud Dirjen Dikti, Jakarta.

Darwis, Ratinus, 1992., Olahraga Pilihan Sepaktakraw. Depdiknas, Jakarta.

Hadi, Sutrisno, 1990., Analisis Regresi. Andi Offset, Yogyakarta.

Halim Ichsan Nur, 2004., Tes dan Pengukuran Kesegaran Jasmani. Universitas Negeri Makassar, Makassar.

Kusuma, Dede, 1989., Olahraga dan Manfaatnya. CV. Karya Ilmiah, Jakarta.

Rani, Adib,Abd. 1993. Ilmu Jiwa Gerak. Bahan kuliah FIK UNM Makassar. Soebroto, Moeh. 1975. Masalah-Masalah Dalam Kedokteran Olahraga, Latihan Olahraga, dan Coaching. Dirjen Pendidikan Luar Sekolah dan Olahraga, Depdikbud RI, Jakarta.

Slameto, 2010. Belajar dan factor-faktor yang mempengaruhi, jakarta Rineka cipta.

Sajoto, Mochamad, 1988., Pembinaan Kondisi Fisik dalam Bidang Olahraga. Depdikbud Dirjen Dikti, Jakarta.

Syarifuddin, 1994., Sepak Takraw. PB. Persetasi, Jakarta.

Tola, Ismail, 1998., Permainan Sepak Raga dan Sepak Takraw. FIK UNM, Makassar.

Yahya,Kasmad. M, 1986., Struktur dan Ramburambu Penulisan Skripsi. Makalah Seminar Ilmiah FIK UNM 